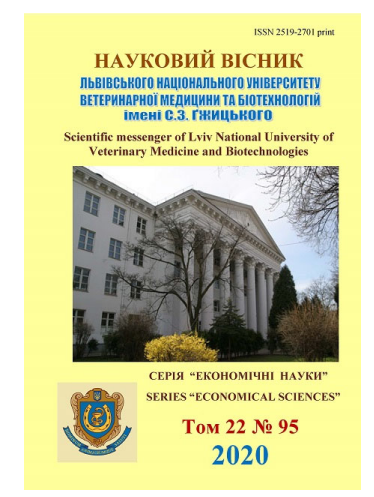

Науковий вісник Дьвівського національного університету
ветеринарної медицини та біотехнологій імені С.3. Гжицького. Серія: Економічні науки

\author{
Scientific Messenger of Lviv National University \\ of Veterinary Medicine and Biotechnologies. \\ Series: Economical Sciences
}

UDC 368:54

\title{
Foreign experience of agricultural insurance and prospects of its adaptation in Ukraine
}

\author{
J. Muzychka, O. Dadak \\ Stepan Gzhytskyi National University of Veterinary Medicine and Biotechnologies Lviv, Ukraine
}

Article info

Received 01.09.2020

Received in revised form 02.10 .2020

Accepted 05.10.2020

Stepan Gzhytskyi National University of Veterinary Medicine and Biotechnologies Lviv, Pekarska Str., 50, Lviv, 79010, Ukraine.

Tel.: +38-067-337-07-50

E-mail:jmuzychka@ukr.net

\begin{abstract}
Muzychka, J., \& Dadak, O. (2020). Foreign experience of agricultural insurance and prospects of its adaptation in Ukraine. Scientific Messenger of Lviv National University of Veterinary Medicine and Biotechnologies. Series: Economical Sciences, 22(95), 22-26. doi: 10.32718/nvlvet-e9504
\end{abstract}

In the articles of the considered process of agrarian insurance in foreign countries. The essence of the concept of "agricultural insurance" and "agricultural insurance risk" is revealed. The history of development of agricultural insurance in the international market of insurance services is studied. There are several well-known national agricultural insurance systems and their characteristics. The national systems and participants of agrarian insurance in the countries of the world, namely: the United States of America, Canada, Spain, Portugal, Italy, Austria, France, Germany, Latvia and Poland are singled out. It is proved that in most countries of the world the importance of insurance of risks of agricultural production as an irreplaceable financial and economic lever of development of agriculture and economy of the countries is described. The most important measures that are provided and mandatory for the participants of the abovementioned foreign national agricultural insurance systems are highlighted. Models of agricultural insurance in different countries are characterized by certain features: the state is an active participant in the agricultural insurance system; insurance is overwhelmingly voluntary; state policy in the field of insurance is characterized by structure and transparency; the state subsidizes both agricultural producers and insurance companies; Appropriate state institutions and appropriate levers of financial influence are created for the development and implementation of state policy in the field of agricultural insurance. Based on the experience of foreign countries, three main operating systems of agricultural insurance protection have been identified: the system of catastrophic coverage, the system of state administration of agricultural insurance programs, the system of cooperation between the state and insurance companies. It is noted that there is also an inefficient system of "state insurance company", which sells agricultural insurance services. The main normative acts regulating the insurance process in Ukraine are described. It was proposed to introduce a new program of state support for agricultural insurance, which would clearly define: the subjects of the market of insurance of agricultural products with state support, insurance contracts, insurance rules, the mechanism for providing state support to farmers; information support of state support of agricultural insurance.

Key words: insurance, agroinsurance, agrarian insurance systems, state support of insurance, agriculture.

\section{Зарубіжний досвід аграрного страхування та перспективи його адаптації в Україні}

Ю. М. Музичка, О. О. Дадак

Львівський національний університет ветеринарної медицини та біотехнологій імені С. 3. Гюсиького, м. Львів, Україна

У статті розглянуто процес аграрного страхування у зарубіжних краӥнах. Розкрито сутність понять “аграрне страхування” та “аграрний страховий ризик”. Вивчено історію розвитку сільськогосподарського страхування на міжнародному ринку страхо- 
вих послуг. Виділено кілька відомих національних систем аграрного страхування та їх особливості. Виокремлено національні системи та учасників аграрного страхування у країнах світу, а саме: США, Канада, Іспанія, Португалія, Італія, Австрія, Франція, Німеччина, Латвія і Польща. Доведено, шу у своїй більшості краӥни світу опираються на важливість страхування ризиків аграрного виробництва як незамінного фінансово-економічного важеля розвитку сільського господарства і економіки краӥни. Висвітлені найважливіші заходи, які передбачені та обов'язкові до виконання учасниками вищезгаданих зарубіжних національних систем сільськогосподарського страхування. Моделі аграрного страхування в різних краӥнах характеризуються певними особливостями: держава є активним учасником у діяльності системи сільськогосподарського страхування; страхування в переважній більшості є добровільним; державна політика у сфері страхування відзначається структурністю та прозорістю; держава субсидіює як виробників сільськогосподарської продукції, так і страхові організачї; для вироблення та реалізації державної політики у сфері агрострахування створюються відповідні державні установи та важелі фінансового впливу. На основі досвіду зарубіжних краӥн визначено три основні діючі системи страхування сільськогосподарського захисту: система катастрофічного покриття, система державного управління програмами страхування сільського господарства, система співпраці держави та страхових компаній. Зазначається, щзо існує також неефективна система “державної страхової компанії, яка продає послуги зі страхування сільського господарства. Описано основні нормативні акти, щцо регулюють страховий процес в Украӥні. Запропоновано запровадити нову удосконалену програму державної підтримки сільськогосподарського страхування, яка чітко визначала б: суб'єкти ринку страхування сільськогосподарської продукції з державною підтримкою, договори страхування, правила страхування, механізм надання державної підтримки фермерам; інформачійне забезпечення державної підтримки сільськогосподарського страхування.

Ключові слова: страхування, агрострахування, системи аграрного страхування, державна підтримка страхування, сільське господарство.

\section{Ветуп}

Діяльність ринку аграрного страхування в межах держави та світу вимагає виявлення проблем функціонування для формулювання потенційних перспектив його розвитку як вагомої передумови посилення страхового захисту аграрних виробників. Страхування $є$ одним із елементів, що гарантує стабілізацію фінансового стану сільськогосподарських підприємств в ринкових умовах, забезпечує безперервність розвитку аграрного виробництва, функціонування ринку аграрної продукції та може бути потенційним джерелом залучення інвестицій у сільське господарство.

Мета і завдання дослідження. Метою дослідження $є$ оцінка та узагальнення світових систем та форм аграрного страхування в розвинутих країнах, а також виокремлення дієвих елементів, які можна в перспективі застосувати на вітчизняному страховому ринку.

\section{Матеріал і методи досліджень}

Об'єктом дослідження є напрацювання розвитку закордонного ринку аграрного страхування. Дослідження здійснювались за рахунок застосування загальноприйнятих наукових методів порівняльного аналізу стану розвитку аграрного страхування у іноземних країнах, їх законодавчих основ, регулюючих норм існуючих практик в сільськогосподарському страхуванні, аналіз фінансових механізмів державної підтримки агрострахування. Для дослідження використовувалися загальнонаукові методи і прийоми: метод логічного аналізу, методи порівняння, групування та аналогій, метод системного, теоретичного і практичного матеріалу. Інформаційною базою для досліджень слугували нормативні та законодавчі акти, наукові публікації з проблем аграрного страхування в Україні та закордоном, аналітичні дослідження.

\section{Результати та їх обговорення}

В сьогоднішньому економічному світі аграрне страхування визнане одним із найбільш надійних та ефективних інструментів управління сільськогосподарськими ризиками. Аграрне страхування - це меха- нізм управління усіма сільськогосподарськими ризиками, який забезпечує часткову або повну компенсацію суб'єкту господарювання втрат через негативний вплив природних ризиків (Muzychka et al., 2019).

Страхування у сільському господарстві зародилось в Свропі на межі 20-х років XIX століття як один зі методів захисту від фінансових ризиків. Втрати в сільському господарстві, а саме у тваринництві, можуть настати через загибель поголів'я тварин в результаті захворювань, епідемій, нещасних випадків тощо. Також від пошкодження посівів сільськогосподарських культур, які спричинені природними катаклізмами (град, посуха, повінь, затоплення, пилові бурі тощо). Загалом ризики, які виникають у сільському господарстві, теоретично розділяють за п'ятьма групами: природні ризики, які несуть негативний вплив на отримання аграрної продукції внаслідок несприятливих погодних умов; антропогенні ризики, які впливають на якість грунтів, спричинюють до втрати грунтового покриття, зменшують поживні речовини та порушують природний баланс (вітрова та водна ерозія, погіршення структури грунтів, постійне збіднення грунтів на гумус і поживні речовини); техногенні ризики, які негативно впливають на якісний стан грунтів, знижують врожайність екологічно чистої аграрної продукції (хімічне та фізичне забруднення грунтів, використання пестицидів та мінеральних добрив поза нормами, забруднення грунту отрутохімікатами, паливно-мастильними матеріалами, засоленість і перезволоження земель); еколого-економічні ризики - мають негативний вплив на якість і конкурентоспроможність аграрної продукції на продовольчих ринках країни і світу (використання у процесі виробництва сільськогосподарської продукції екологічно небезпечних технологій); радіаційні ризики, які призводять до розповсюдження радіоактивних матеріалів на аграрну продукцію, що спричиняе зниження іiі якості та/або робить їі непридатною для використання і споживання (Tretjak, 2019).

Загальний світовий досвід свідчить, що країни, уряди яких вбачали (і вбачають) у сфері страхування важливий фінансовий інструмент забезпечення продовольчої безпеки держави та зменшення можливих витрат 3 державного бюджету через несприятливі 
природні умови та інфекційні хвороби тварин, посилено розвивали аграрне страхування протягом останніх 60-70 років. Звідси і виділились кілька відомих національних систем аграрного страхування. Варто зазначити, що кожна держава створює унікальні сис- теми захисту аграріїв, оскільки відображає в собі історичні, економічні, природні, нормативні, регіональні та ментальні особливості. Також на кожному національному ринку аграрного страхування присутні властиві йому учасники (табл. 1).

\section{Таблиця 1}

Національні системи аграрного страхування та їх учасники у країнах світу

\begin{tabular}{|c|c|}
\hline Країни & Учасники систем аграрного страхування \\
\hline Сполучені Штати Америки & $\begin{array}{l}\text { Федеральна корпорація страхування; } \\
\text { Департамент сільського господарства; } \\
\text { страхові компанії; } \\
\text { товариства взаємного страхування }\end{array}$ \\
\hline Канада & $\begin{array}{l}\text { Державна корпорація страхування аграрних ризиків; } \\
\text { страхові компанії; } \\
\text { товариства взаємного страхування }\end{array}$ \\
\hline Іспанія & $\begin{array}{l}\text { Державне Агентство аграрного страхування при Міністерстві сільського господарства; } \\
\text { Консорціум Компенсації страхування; } \\
\text { Головне управління страхування при Міністерстві економіки; } \\
\text { страховий аграрний пул; } \\
\text { Федерація сільськогосподарських кооперативів }\end{array}$ \\
\hline Португалія & Система «державного та приватного партнерства» \\
\hline $\begin{array}{l}\text { Італія, } \\
\text { Австрія, } \\
\text { Франція, } \\
\text { Німеччина }\end{array}$ & $\begin{array}{l}\text { Страхові компанії: розроблення страхових продуктів зі страхування аграрних ризиків. } \\
\text { Держава: контроль за здійсненням страхового та перестрахувального захисту сільського- } \\
\text { сподарських товаровиробників. }\end{array}$ \\
\hline Латвія & $\begin{array}{l}\text { Міністерство землеробства; } \\
\text { страхові компанії }\end{array}$ \\
\hline Польща & Приватна система страхування під контролем держави \\
\hline
\end{tabular}

Джерело: складено авторами на основі (Malik \& Gudz', 2015)

Кожна із наведених у таблиці систем страхування в сільському господарстві відзначається, головно, заходами, які передбачені та обов'язкові до виконання iii учасниками. Так, для США основними заходами будуть - забезпечення виконання Федеральної програми страхування врожаю, яка включає: перерахунок страховикам із федерального бюджету за фермерів $60 \%$ страхових премій; контроль організації перестрахування; забезпечення додаткового страхового покриття фермерам, які беруть участь у Федеральній програмі страхування врожаю; забезпечення перестрахування понад $40 \%$ ризиків агропромислового комплексу закордоном.

Канада основними заходами в аграрному страхуванні визначила - забезпечення виконання Державної програми страхування аграрних ризиків, яка передбачає: виконання програми забезпечення доходів; субсидовані заощадження для фермерів; контроль організації перестрахування; забезпечення перестрахування понад $40 \%$ аграрних ризиків закордоном.

В Іспанії, в порівнянні з іншими країнами, більше учасників системи агрострахування, які займаються вирішенням досить широкого кола питань. Відповідно, Державне Агентство аграрного страхування займається затвердженням щорічного урядового плану страхування аграрних ризиків, який містить: список видів аграрних культур, тварин і риб, які підлягають страхуванню; умови страхування (встановлені періоди страхування певних культур); розділ бюджетного фінансування страхування (складається з агропромислового i фінансово-страхового аспектів); надання субсидій аграріям для сплати страхових премій; комплекс необхідних сільськогосподарських робіт; забезпечення системи перестрахування за кордоном. Консорціум Компенсації страхування забезпечує: організацію внутрішнього перестрахування; формування й функціонування стабілізаційного фонду. Головне управління страхування здійснює контроль за діяльністю ринку аграрного страхування. Страховий аграрний пул допомагає страховикам у здійсненні страхування аграрних ризиків. Федерація сільськогосподарських кооперативів займається: захистом інтересів членів кооперативів при аграрному страхуванні; наданням інформації щодо програм страхування аграрних ризиків.

В Португалії, де діє система “державного та приватного партнерства”, ролі по здійсненню основних заходів в аграрному страхуванні розподілені таким чином, що держава займається субсидіюванням фермерів при страхуванні та організації перестрахування. Приватні страхові компанії, які надають послуги зі страхування сільськогосподарських ризиків займаються: розробленням програм страхування та контролем за їх виконанням; відшкодуванням частини ризиків, які не відшкодовуються державою.

Італійській, німецькій, французькій та австрійській системам аграрного страхування притаманний такий розподіл виконання страхових заходів, коли страхові компанії займаються розробленням страхових продуктів зі страхування ризиків, а держава здійснює контроль страхового та перестрахувального захисту аграрних товаровиробників. Для прикладу у Німеччині не 
передбачено виплат субсидій, оскільки основними гравцями на ринку страхування є страхові (недержавні) компанії. Проте в країні функціонують програми ситуативних виплат 3 державного бюджету при настанні стихійних лих, виплати за якими відбуваються лише при умові одержання дозволу Європейського Союзу.

У Латвії Міністерство землеробства забезпечує: субсидування страхових премій; створення накопичувального фонду за участю держави, сільськогосподарських товаровиробників та страхових компаній; створення компенсаційного фонду за участю сільськогосподарських товаровиробників і держави.
Основним заходом в аграрному страхуванні у Польщі $\epsilon$ забезпечення функціонування Страхового гарантійного фонду для здійснення $100 \%$ виплат страхового відшкодування за договорами обов'язкового страхування відповідальності осіб, які зайняті в сільському господарстві (Prokopchuk et al., 2014; Tanklevs'ka \& Jarmolenko, 2020).

Виходячи $з$ досвіду іноземних країн, можна виокремити три основні системи аграрного страхового захисту (Prokopchuk et al., 2014), які проілюстровані на рисунку 1.

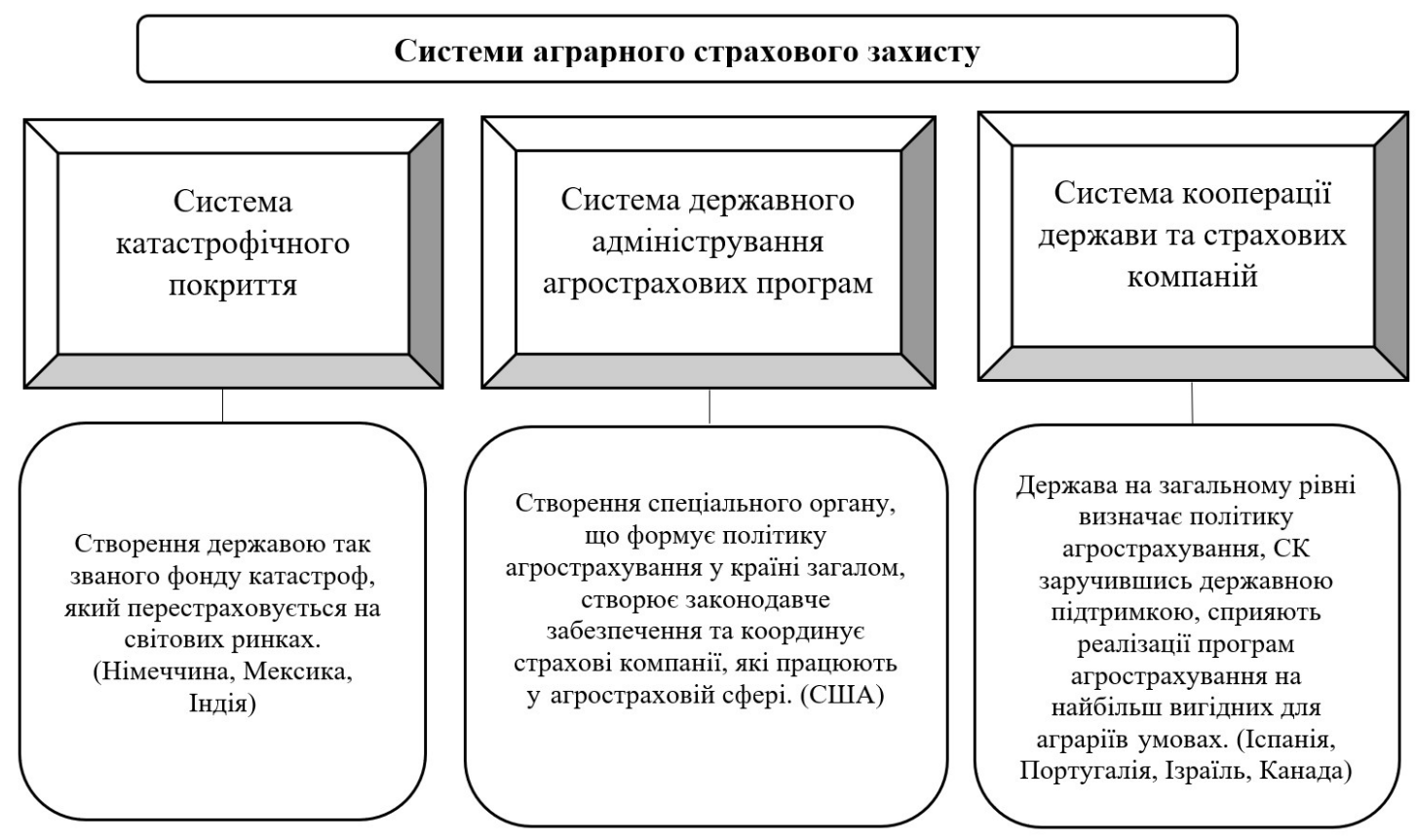

Рис. 1. Системи аграрного страхового захисту*

*Узагальнено авторами на основі джерел: (Prokopchuk et al., 2014; Shyshpanova et al., 2018)

Варто зазначити, що існує також система “державної страхової компанії”, яка реалізовує агрострахові послуги (Білорусь, Греція, Кіпр). Проте досвід такої практики вказує на їі надто низьку ефективність.

У більшості аграрних країн світу саме страхування $\epsilon$ одним із основних заходів захисту від ризиків втрати врожаю, проте в Україні страхування в аграрному секторі доволі слабо розвинуте. Згідно статистичних даних найактивніше страхуванням ризиків займаються великі аграрні компанії, які частково вимушені це робити для залучення фінансування від банківських установ, оскільки це є вимогою при фінансуванні під заставу майбутнього урожаю (Tanklevska \& Yarmolenko, 2018).

Основним нормативним актом, який регулює страхування в Україні є Закон України "Про страхування”. Цей Закон регулює відносини у сфері страхування і спрямований на створення ринку страхових послуг, посилення страхового захисту майнових інтересів підприємств, установ, організацій та фізичних осіб (Zakon Ukrai'ny Pro strahuvannja...). 3 метою залучення підтримки збоку держави 9 лютого 2012p. було прийнято Закон України "Про особливості стра- хування сільськогосподарської продукції з державною підтримкою”. Вищезгаданим законом врегульовуються відносини у сфері страхування сільськогосподарської продукції, що здійснюється 3 державною підтримкою, з метою захисту майнових інтересів сільськогосподарських товаровиробників і спрямований на забезпечення стабільності виробництва в сільському господарстві (Zakon Ukrai'ny Pro osoblyvosti ...).

Державна підтримка в Україні полягає в компенсації аграріям 3 державного бюджету грошових коштів у вигляді субсидій для оплати частини страхової премії нарахованої за договором страхування. Проте цей механізм фактично не діє. Варто згадати, що з 01 липня 2020 р. регулятором страхового ринку замість Національної комісії, яка здійснює державне регулювання у сфері ринків фінансових послуг, став Національний банк України, що також стає основою до певних змін на страховому ринку України (Strahuvannja agrosektora...). 


\section{Висновки}

Моделі аграрного страхування в різних країнах характеризуються певними особливостями: держава $\epsilon$ активним учасником у діяльності системи сільськогосподарського страхування; страхування в переважній більшості є добровільним; державна політика у сфері страхування відзначається структурністю та прозорістю; держава субсидіює як виробників агропродукції, так і страхові організації; для вироблення та реалізації державної політики у сфері агрострахування створюються відповідні (профільні) державні установи; загалом, країни з успішним досвідом у агрострахуванні напрацювали його впродовж відносно тривалого історичного періоду.

Очевидно, що без підтримки з боку держави аграрне страхування в Україні повноцінно працювати не зможе. Звідси, важливим є впровадження нової удосконаленої програми державної підтримки сільськогосподарського страхування, в якій були б чітко визначені: суб'єкти ринку страхування агропродукції 3 державною підтримкою (вимоги, права та обов'язки); договори страхування (права, обов'язки сторін, предмет договору тощо); правила страхування, (страхові ризики, випадки, суми, платежі тощо); механізм надання державної підтримки аграріям; інформаційний супровід державної підтримки процесу агрострахування.

Перспективи подальших досліджень. Враховуючи те, що ведення підприємницької діяльності у сільському господарстві $€$ високо ризикованим, питання використання страхування агроризиків, як методу зменшення майбутніх втрат, є актуальним та необхідним. Перспективи для майбутніх досліджень полягають у необхідності здійснення прогнозів та рекомендацій щодо подальшого страхування агрокультур та сільськогосподарських тварин, а також визначення найбільш ефективних страхових продуктів та для аграріїв із врахуванням успішного зарубіжного досвіду.

\section{References}

Malik, M., \& Gudz', G. (2015). Organizacija strahovogo zahistu u agrarnomu pidpriєmnictvi zarubizhnij dosvid. Ekonomika, 8(173). 19-25. doi: 10.17721/17282667.2015/173-8/3 (in Ukrainian).
Muzychka, J., Muzyka, P., \& Dadak, O. (2019). Stan ta tendencii' rozvytku rynku agrarnogo strahuvannja Ukrai'ny. Naukovyj visnyk LNUVMB imeni S.Z. G'zhyc'kogo. Serija: Ekonomichni nauky, 21(92), 25-28. URL: https://nvlvet.com.ua/index.php/economy/ article/view/3695/3741 (in Ukrainian).

Prokopchuk, O. T., Uljanych, Ju. V., \& Bechko, V. P. (2014). Osoblyvosti strahuvannja agrarnyh ryzykiv u krai'nah svitu. Aktual'ni problemy ekonomiky, 3(153), 46-53. URL: http://lib.udau.edu.ua/handle/ 123456789/750 (in Ukrainian).

Shyshpanova, N. O., Sovshhak, S. S., \& Mel'nyk, Ju. V. (2018). Zarubizhnyj dosvid agrarnogo strahuvannja ta mozhlyvosti jogo vprovadzhennja u vitchyznjanu strahovu praktyku. Global'ni ta nacional'ni problemy ekonomiky, 22, 872-876. URL: http:/globalnational.in.ua/archive/22-2018/164.pdf (in Ukrainian).

Strahuvannja agrosektora v Ukrai'ni. URL: https://biz.ligazakon.net/analitycs/195897_strakhuvan nya-agrosektora-v-ukran (in Ukrainian).

Tanklevs'ka, N. S., \& Jarmolenko, V. V. (2020). Perspektyvy adaptacii' zarubizhnogo dosvidu agrostrahuvannja v Ukrai'ni. Ekonomika harchovoi' promyslovosti, 12(1). doi: 10.15673/fie.v12i1.1669 (in Ukrainian).

Tanklevska, N. S., \& Yarmolenko, V. V. (2018). Tendentsii rozvytku strakhuvannia silskohospodarskykh kultur v Ukraini. Naukovyi Visnyk Uzhhorodskoho Universytetu, 1(51), 381-386. doi: 10.24144/2409-6857.2018.1(51).381-386 (in Ukrainian).

Tretjak, K. V. (2019). Agrostrahuvannja: zarubizhnyj dosvid ta resursy shhodo jogo implementacii' v ukrai'ns'ku strahovu praktyku. Elektronne naukove fahove vydannja "Efektyvna ekonomika", 1. URL: http://www.economy.nayka.com.ua/pdf/1_2019/34.pd $\mathrm{f}$ (in Ukrainian).

Zakon Ukrai'ny Pro osoblyvosti strahuvannja sil's'kogospodars'koi' produkcii' z derzhavnoju pidtrymkoju. URL: $\quad$ https://zakon.rada.gov.ua/laws/show/439117\#Text (in Ukrainian).

Zakon Ukrai'ny Pro strahuvannja. URL: https://zakon.rada.gov.ua/laws/show/85/96$\%$ D0\%B2\%D1\%80\#Text (in Ukrainian). 